\title{
THE EXISTENCE OF ADAT LAW COMMUNITY IN PUBLIC-PRIVATE PARTNERSHIP
}

\author{
Karina Dwi Nugrahati Putri ${ }^{1}$, Sartika Intaning Pradhani ${ }^{2}$; Hendry Julian Noor ${ }^{3}$ \\ 1,2,3 Lecturer at Faculty of Law, Universitas Gadjah Mada \\ Email: ${ }^{1}$ karina@mail.ugm.ac.id; ${ }^{2}$ sartika@mail.ugm.ac.id; \\ 3hendryjuliannoor@mail.ugm.ac.id
}

\begin{abstract}
Article Information
Submitted: 22 November 2018

Reviewed : 11 January 2019

Accepted : 31 Desember 2020

Keywords :

Adat Law Community; Public-

Private Partnership; Fair

Replacement Value
\end{abstract}

Abstract
This paper aimed to elaborate the participation of Adat Law Community
in Public-Private Partnership (PPP) to introduce new approach to
replace compensation to more participative and collaborative scheme of
infrastructure development in PPP. This article uses the normative legal
research with the conceptual, statute, and case approach. This research
show that releasing the land used for infrastructure development
procurement will abolish the identity of the community. It have shown
that failure in recognizing Adat Law Community as rightful party over
their land neglects their right to entitle compensation. Furthermore,
instead of economically compensating ulayat land of Adat Law
Community, used for infrastructure development, Adat Law
Community's participation shall be involved in infrastructure
development on their land. The active participation of Adat Law
Community can be exercised through placing the community as public
entity in PPP. For comparison in China, the State does not pay according
to marketprices to farmers. However, it provides a compensation package
that includes employment opportunities for farmers, housing
compensation, compensation for crop loss, and / or granting a residence
permit in urban areas. This make them eligible for their social welfare
such as health insurance, pensions and / or retirement plans, access to
high-quality schools and subsidized agricultural goods that were not
previously available to farmers

\section{Introduction}

The spectrum of government role as an executor for delivering public services is very broad yet the capacity and resource availability are limited. The limitation of the government's capacity to deliver public services encourages the government to perform more strategically. One of the mechanisms to do that is through collaborative actions with other stakeholders. Prominent collaborative action for public procurement for developing infrastructure is the Public-Private Partnership (hereinafter abbreviated to PPP) scheme (Indonesian Government Mid-Term Planning 2015-2019; Burger and Hawkesworth 2011: 1). The mechanism of PPP has been assumed as a 'perfect' collaboration because it bridges the interests of both private and public entities.

In implementing PPP for Indonesian infrastructure development, there are numerous agrarian conflicts arising in land procurement stage due to its mismatching perspective between stakeholders (Weihe, 2008: 157)1. Conflict on land procurement sometimes is inevitable because land procurement for public interest neglects non-legal 
variables which strongly relevant and influential (Koeswahyono 2008: 33). Agrarian Reformation Consortium records that since 2015-2017 there are 1.361 manifest conflicts; and in 2017 there are 657 agrarian conflicts in 520.491,87 hectares land involving 652.738 families (Agrarian Reformation Consortium, 2017). Agrarian Reformation Consortium reports that agrarian conflicts are conflicts based on sector where there were 92 conflicts in infrastructure procurement. According to identification conducted by Coalition for Law Reform based on Society and Ecology, HuMa, during agrarian conflicts, victims are communal groups, not individual, such as indigenous peoples (Widiyanto, et. al.2012: 8).

The communal groups in the area of the project felt that they are victims of infrastructure procurement on behalf of development. On the other side, the government felt that they already invited the community through meeting, which can be called as Free Prior and Informed Consent (FPIC). During the FPIC stage, the community shall have a chance to hear the development plan, but somehow the aspiration is not always be heard and implemented. Subsequently, they did not have a chance to raise their voice in deciding the 'next plan' toward their land because their participation as an actor in PPP scheme least heard. Have they participated, their participation is often counted as formality in order to fulfil the procedure of land procurement. Unfortunately, this nonparticipatory trend is continuing, even the concept of FPIC has been highly promoted ${ }^{3}$. By considering the absent of active participation of the community in land procurement for infrastructure, PPP shall be more collaborative and participative (Bell and Hindmoor 2009: 186).

There are numbers of communities living in Indonesia. People living in Indonesia are united as a law community under Indonesian Law. Law community has legal authority, legal enforcers, separated wealth used for the people's interest and welfare, and ability to conduct legal relation (Iman Sudiyat, 1978: 51). Law community is the more specific term compared to community itself. Law community is the translation of rechtsgemeenschap; which means, as a group of humans whose not only psychologically attached to each other, but also perceives themselves as a unitary since they live under the same legal system (Pujosewojo, 1971: 14). Adat Law Community is a distinct law community living in Indonesia. Adat Law Community is a group of people which has ancestral origin in particular geographical territory and has their own value system, ideology, economy, politics, culture, social, and territory (Nugroho 2008: 199). Since 1998, Adat (Law) Community as part of Indonesian society is promoted by activist to be defined as indigenous peoples in Indonesia (De Royer, 2015: 5).

Indigenous peoples are losing out to local elites and domestic or foreign investors because they lack the power to claim their rights effectively and to defend and advance their interest (Oxfarm, 2011: 3). Traditional right of Adat Law Community is ulayat right (Kusumadara, 2013: 2). Adat Law Community can exercise their existing conditional ulayat right and any right similar to it. Minister of Home Affair and Faculty of Law Universitas Gadjah Mada defines ulayat right as legal term which attach to distinct competence of Adat Law Community in the form of authority or control to manage and to regulate land and its content which internally and externally binding (Minister of Home Affair and Faculty of Law Universitas Gadjah Mada, 1978). 
Ulayat right is similar to beschikkingrecht in Adat Law literature. Beschikkingrecht is term introduced by Van Vollenhoven which explained by Ter Haar as right of a group of people to internally regulate how the members collect resource from their land and to externally restrict outsider take unlawful benefit from their land (Ter Haar, 2013: 49-50; Sumardjono, 2018: 37). Ter Haar proposes that right to bechikken is absolute, including right to transfer land title. But according to Van Vollenhoven, as cited by Ter Haar, one of beschikkingrecht distinct character is prohibition to transfer the land title (Ter Haar 2013: 50). Ulayat right which refers to beschikkingrecht is right to control land, but it restricts land transfer.

Another distinct character of ulayat right held by Adat Law Community is its characters which has both private and public nature. Burns, as cited by Davidson and Hendley, says that in its private nature, ulayat right can be equivalent to ownership right as it encompass civil law ownership (Davidson and Hendley, 2007: 133). In its public nature, ulayat right shall be excluded from all forms of private ownership (Davidson and Hendley, 2007: 133). Later, ulayat right is adopted by Indonesia as state right to control.

Moreover, in its Constitution, Republic of Indonesia recognizes and respects Adat Law Community along with their traditional rights. Minister of Home Affair in its regulation defines Adat Law Community as Indonesian citizen which has distinct character, lives in group harmoniously according to their Adat Law, has ancestral bonding and/or similar residence, has strong relationship with land and environment, and has value system which determines economic, politics, social, culture, law, and utilization of territory hereditary (Minister of Home Affair Regulation Number 52 of 2014 regarding guideline to recognize and to respect Adat Law Community). While Minister of Forestry and Environment in its regulation defines Adat Law Community as a group of hereditary community who lives in particular geographical territory based on genealogical bonding, livelihood bonding, and value system which determines their economic, political, social, and law structure (Minister of Forestry and Environment Regulation Number 32 of 2015 regarding Forest with Title).

Though Adat Law Community has strongly recognized by law, yet in practice the participation of Adat Law Community in government's projects is usually disregarded. The community is perceived as an obstruction of government's programs (Rahmi, 2010: 355). Socially and culturally, indigenous people's way of life is seen as symbols of underdevelopment, backwardness and the obstacle of modernization (Erni, 2008: 268). During infrastructure development under PPP scheme, the necessity over land is a substantial element. The title of land used for infrastructure development may vary. It can be individual land, state land, Adat Law Community's land, or land with any other titles. Land used for infrastructure development for public interest under PPP scheme shall be under state land title; therefore individual or Adat Law Community shall release their land when their land are used for PPP project. Releasing land title terminates legal relation between the right holder and the object, the land. Meanwhile, existence of Adat Law Community is highly determined by the existence of their land 4 .

Once land right holder releases their land, they shall entitle fair replacement value to compensate their loss. Unfortunately, Adat Law Community is often not entitled 
compensation because the community is not recognized as rightful party of their ulayat land ${ }^{5}$. Even when Adat Law Community receives compensation, the compensation is not satisfactory because it does fairly compensate the loss they suffered due to the different values they have toward the land compared with individuals' perception. This dilemmatic situation should be mitigated to enhance the role of PPP in delivering public interest in one hand without abandoning Adat Law Community's right to determine their life path in term of utilising their land.

By considering the facts mentioned above, this paper will argue that instead of using compensation as fair replacement value, there is an option to involve Adat Law Community as a party of PPP. This must be admitted to be closely related to the fact that sometimes the amount of compensation and / or even increasing the value of compensation, basically it will not necessarily be able to reduce agrarian conflicts that may or have occurred.

Iqra Anugrah stated that although there was a Minister of Finance Regulation No. 13 of 2013 concerning Land Procurement for Development, which previously amounted to $2-3 \%$ of the total development cost to $3-4 \%$, basically it did not and it would be able to overcome the problem of agrarian conflicts, with some of the following reasons (Anugrah, 2019): First, the issue of agrarian conflict between the community and the government or corporation is more complicated than just a conflict over the amount of land acquisition compensation money, which is due to differences in perception. The government tends to measure citizens' land prices low. The government offer is too low, also exacerbated by the mechanism of land acquisition that does not involve the community and wordy. Second, the nature of agrarian conflicts in Indonesia causes an increase in the amount of compensation will not automatically resolve the conflicts, because this relates to the issue of the struggle for living space between the community and the state and corporations that often occur in unequal political and socio-economic relations. This unequal relationship occurs because the political power and funds of both the state government and companies are stronger than the people. In other words, agrarian conflict is basically always structural.

This scheme shall be considered by the government to give a chance for Adat Law Community to exercise its self-determination principle, which has been a struggle for indigenous people around the world. This argument is supported by an international legal framework under United Nation Declaration on the Rights of Indigenous Peoples (UNDRIP) ${ }^{8}$. In national context, the involvement of Adat Law Community can be seen as an alignment of constitution recognition toward the community and their rights 9 . In local level, Adat Law Community as legal subject has been recognized, respected, and protected by local regulation ${ }^{10}$. Considering these hegemony in mainstreaming Adat Law Community as main actor to regulate and manage their own territory in international, national, and local legal framework, conventional view which perceives Adat Law Community as an obstacle toward development is no longer relevant. Public transcript of Adat Law Community should be transformed into a more strategic inclusion to enhance their existence. 
In order to elaborate the participation of Adat Law Community in PPP, analysis in this paper is divided into four parts. First part, land procurement for infrastructure development, explains the procedure to conduct land procurement for infrastructure development. After understanding how the procedure to conduct land procurement, it will be revealed whether there is gap between what the law says and how the law does in second part, practices of compensation as fair replacement value. Compensation is considered as fair replacement value to replace the loss suffered by the rightful parties who loses their land title. Unfortunately, compensation has not fairly compensated the loss, therefore the third part critiques towards compensation as fair replacement value in Adat Law Community's land used for infrastructure development. Lastly, there shall be a new approach to replace compensation to more participative and collaborative scheme of infrastructure development in PPP. A proposal is raised to introduce Adat Law Community as a public entity in PPP.

\section{Research Methods}

The approach method used by the authors in this study is the Normative Juridical approach (Legal Research) (Peter Mahmud Marzuki, 2014) related to Adat Law Community in Public-Private Partnership. The legal materials used by the authors in this study were obtained from the primary law material namely Law Number 2 of 2012 on The Land Procurement for Development of Public Interest, The Government Regulation Number 7 of 2012 on The Implementation of Land Procurement for Development of Public Interest, The Minister Regulation, and Court Decisions. Secondary Legal Material is a library material containing information about primary materials, such as Abstracts, Indices, bibliographies, government issuance, and other reference (Soerjono Soekanto, 2018). The collection of legal materials is done by searching the library/digital library through browsing internet. The materials sought in this study are legal materials in the form of Information on the Adat Law Community in Public-Private Partnership. Materials can produce a conclusion that can be accounted for, then analyzed using descriptive methods of (Peter Mahmud Marzuki, 2017)

\section{Research Result and Analysis}

\section{A. Land Procurement for Infrastructure Development}

In Indonesia, according to Law Number 2 of 2012 regarding Land Procurement for Development of Public Interest, land procurement is an activity to procure land by giving appropriate and fair compensation to the rightful party. Below is the procudure of land procurement for infrastructure development according to Law Number 2 of 2012 regarding Land Procurement for Development of Public Interest and Presidential Regulation Number 71 of 2012 regarding Implementation of Land Procurement for Public Interest Development 


\section{Diagram 1. Land Procurement Procedure}

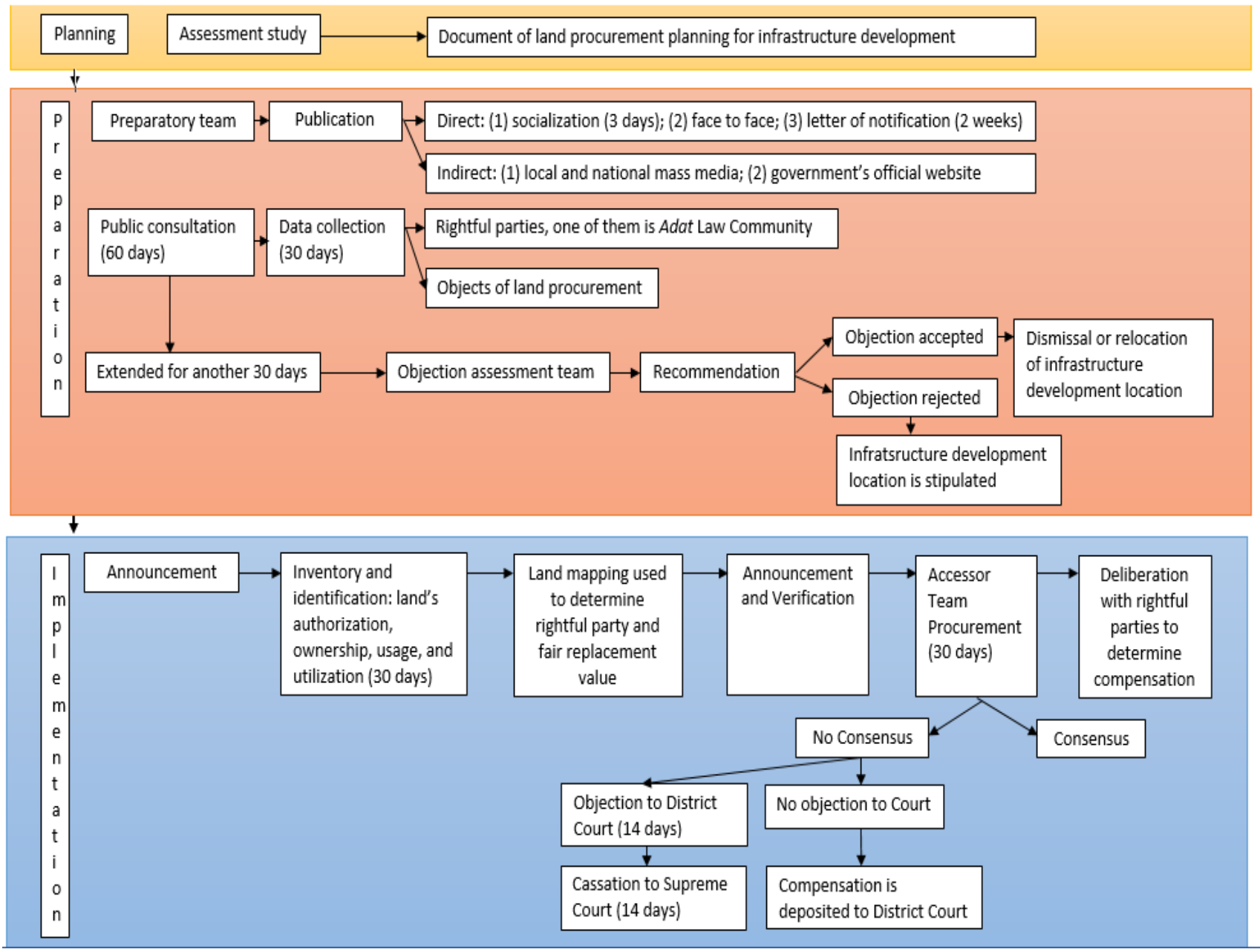


Rightful party is a party who authorizes or owns object of land procurement. Adat Law Community is one of rightful parties which may entitles a compensation when their land (ulayat land) becomes the object of land procurement. Objects of land procurement are land, space above or under land, building, plant, object related to land, or others which can be valued. According to law, compensation over ulayat land shall be given in the form of land replacement, housing, or any other form of compensation agreed by Adat Law Community.

Adat Law Community shall release their ulayat right in land procurement for infrastructure after given compensation or based on legally binding court decision. Unfortunately, Adat Law Community recognition in Law Procurement is also pseudolegal recognition (Nurjaya 2009: 383) because Adat Law Community which can be categorized as rightful party shall meet several conditions. This community shall be a group of people bound by Adat Law. They shall have ulayat land where they take their daily need. There is Adat Law structure which manages, authorizes, and utilizes the ulayat land. This law structure shall be obeyed and applicable for all of the community's member. Another important point is that the Adat Law Community shall be recognized by regional regulation ${ }^{11}$. Meanwhile, requirements as precondition of Adat Law Community recognition create another barrier for them.

According to Presidential Regulation Number 71 of 2012 regarding Implementation of Land Procurement for Public Interest Development, Adat Law Community shall be recognized based on research and stipulated by regional regulation. The community shall be a group of people bound by Adat Law as a union of law community which recognize and implement their law in daily life; have ulayat land in their territory as place where they fulfill their daily life; and have Adat Law order to administer, authorize, and use ulayat land which applicable and obeyed by the member of Adat Law Community.

Land procurement activity starts from planning, preparation and implementation. Government agency which plan to conduct infrastructure development shall arrange document of land procurement (Sapto Hermawan, 2019). This document is arranged based on assessment study. Assessment study includes social economic survey; location feasibility; cost analysis and development benefit for territory and community; land price estimation; environment impact and social impact which may arise from land procurement and development; and other necessary study. The document shall provide information regarding purpose of infrastructure development; conformity with spatial planning and development priority; location of the land; description of land title; time estimation of land procurement; time estimation of infrastructure development; estimation of land value; and budget planning. Location of the land describes administration territory where the land is located, including village, district, regency/municipality; and province. Description of land title explains initial data regarding land ownership or authorization. This document will be handed over to the governor. 
The document will be legal basis for the governor to conduct the preparation step. The governor will appoint a preparatory team. Duties of preparatory team are to inform infrastructure development planning to public; to collect initial data of plan development location; to conduct public consultation; to prepare and announce stipulation of development location; and any other duty assigned by the governor related to the preparation of land procurement. Information on infrastructure development planning can be delivered to public directly or indirectly. Direct information is delivered through socialization, face to face or letter of notification, while indirect information is delivered by mass or electronic media. Socialization invitation shall be distributed to the potential community affected by the project at minimum 3 days before the socialization day. Letter of notification shall be sent to the potential community affected by the project at maximum 20 days after the governor receives document of infrastructure development planning. There shall be at least one publication in national and local mass media regarding the planning of infrastructure development. Provincial government, regional government, and agency which plan to conduct infrastructure development shall post in their website regarding infrastructure development planning.

After the information on infrastructure development planning is published, data concerning location where the infrastructure is planned to be developed are collected, such as data about rightful parties and objects of land procurement. Data shall be collected within 30 working days after the publication of infrastructure development planning. These data are presented in temporary list of development planning location and signed by head of preparatory team. The temporary list of development planning location then feeds as information in public consultation activity.

Since Adat Law Community can be one of the rightful party who authorizes land within the location of development planning, international law instruments recommends state to cooperate with indigenous peoples and they undertake genuine consultations regarding any project affecting their ancestral lands, territories, and resources (United Nations 2012: 3). Therefore, the consultations must meet minimum procedural requirements, including ensuring that the indigenous peoples have adequate information on the proposed measures to meaningfully participate, and that the procedures for consultation are culturally appropriate (United Nations 2012: 5). States and the private sectors must obtain the free, prior and informed consent of indigenous peoples in any planned projects, exercise good faith, and guarantee their full and effective participation and a share in the benefits arising from such projects (United Nations 2012: 5; Feiring, 2013: 59-60; Reynaers 2013: 46).

Normatively, objective of public consultation in Indonesia is to obtain consensus on location of development planning from rightful parties. Public consultation involves rightful parties and community affected by development planning. It can be conducted in location of development planning or in other agreed place. Rightful parties can directly involve or can be represented based on power of attorney. Public consultation shall be conducted at maximum 60 working days. If within 60 working days there is objection, public consultation can be extended for maximum for 30 working days. 
Objection shall be delivered in written to explain the reason of objection. If public consultation has been extended for another 30 days and there is still objection, government agency shall report to the governor. The governor shall appoint an objection assessment team. The team consist of province secretariat as member and head; head of land registrar office; unit of government on region development planning; head of representative ministry of law and human right office; regent/mayor; and academics. Team shall inventory problems being objected; conduct meeting or clarify the objection; and recommend whether the objection shall be accepted or rejected. Team shall deliver the recommendation to governor at maximum 14 working days after the governor received the objection. If the governor rejects the objection, location of development planning is stipulated. If the governor accepts the objection, government agency shall propose another location for development planning. When the location has been stipulated and there is still objection, within 30 days working days rightful party can submit claim to Administrative Court. Administrative Court Decision shall decide the claim within 30 working days. Party which unhappy with Administrative Court Decision can appeal directly within 14 working days to Supreme Court. Supreme Court shall decide the appeal within 30 working days. Legally binding court decision shall be the legal basic whether land procurement shall be continued.

Consensus achieved during public consultation shall be documented in minutes of consensus. Minutes of consensus is the basic of government agency to submit proposal to stipulate location of development planning to governor. Governor shall stipulate the location at maximum 14 working days after the proposal received. Location stipulation is the start of land procurement implementation conducted by Land Agency. Land procurement is implemented by inventory and identify authorization, ownership, use, and utilization of land; compensation valuation, deliberation to stipulate compensation, giving compensation, and release of land. After location is stipulated, rightful parties shall only transfer their land title to government through land agency. Transfer of land title is conducted by giving compensation which value is stipulated together with publication of location stipulation.

Inventory and identification of land authorization, ownership, use, and utilization shall be conducted at maximum 30 working days to measure and to map land; and to collect data on rightful parties and objects of land procurement. Result of inventory shall be published gradually, partially, or entirely in village office, district office, and location of land procurement. Objection towards inventory result shall be submitted at maximum 14 working days after inventory result is published. Published inventory result and its correction, if any, shall become the legal basic to determine rightful parties who entitle compensation.

In order to determine compensation, Land Agency shall appoint accessor to value object of land procurement, such as land, space above or under land, building, plant, object related to land, or other loss which can be valued. Other loss which can be valued is non-physical loss equal to money, such as loss of business or job, cost of moving, shift of profession, and value of residual property. Value of compensation evaluated by accessor is calculated based on value when location is stipulated for development 
planning. Value of compensation based on accessor valuation documented in minutes and reported to Land Agency is the basic of deliberation to stipulate compensation. Compensation can be given in the form of money, replacement land, resettlement, share ownership, or combination between them.

Deliberation shall be conducted at maximum 30 working days. If the deliberation does not achieve consensus, rightful party can object by submitting claim to District Court at maximum 14 days after deliberation of compensation valuation is conducted. District Court shall decide the claim within 30 working days. Party who unsatisfied with District Court Decision can submit appeal to Supreme Court at maximum 14 working days after the decision issued. Supreme Court shall decide the appeal within 30 working days. Legally binding court decision is legal basic to value compensation to rightful party who submit objection. If rightful parties reject the form and/or the value of compensation, but they do not submit objection. They are considered to accept the compensation. Compensation shall be given directly to rightful person or representative based on letter of attorney. If the rightful party rejects the compensation, compensation shall be deposited to District Court. When compensation has been given or deposited, land title has been released from rightful person and land is under control of the state. Release of right is termination of legal relation from rightful party to state land (Kusumadara 2013: 7) through Land Agency.

\section{B. Practices of Compensation as Fair Replacement Value}

Following the procedure of land procurement in Indonesia, consultation which shall be a mechanism to deliver adequate information in order to invite meaningful participation of Adat Law Community in the planned project is limited as a mechanism to gain support from community by consented to the planned project and value of compensation. In law on land procurement, rights of the community are limited to know the planned project and to obtain information regarding land procurement. People are obliged to follow the law on land procurement and may give oral or written input and support in implementation of land procurement. By considering the current land procurement law, structural conflict between rightful parties as party which has right over land and government as party which needs land will continue because rightful parties does not feel legally protected by considering value of compensation and government is forced to accelerate land procurement through repressive mechanism, such as deposited money to District Court even without consent from rightful party regarding value of compensation which can guarantee their wellbeing (Ismail 2012: 48).

In 2011, Parengnge Dada Saruram VIII, head of Saruan Adat Law Community, sues Regent of Tana Toraja, Sangpuloh Adat Law Community, and persons who receive compensation. Claimant argues that the government has wrongly compensated persons during land procurement in Mengkedek District for Airport Development. Both claimant and defendant agree that the disputed land is ulayat land. During land dispute, land certificate is strong legal proof during the Court session. Since Saruan Adat Law Community can not show Certificate of Land Ownership as proof of their authorization 
towards the ulayat land. Makale District Court Decision Number 81/Pdt.G/2011/PN.MKL, dated 22 June 2012 reject the claim brought by the claimant.

Before the issuance of Land Procurement Law, land procurement is conducted based on Presidential Regulation. Compensation shall be agreed based on deliberation, but if consensus can not be achieved, it shall be calculated based on Sales Value of Taxable Object by land procurement committee; building value valuated by government responsible in building issue; and plant value valuated by government responsible in agriculture issue (Presidential Regulation Number 36 of 2005 regarding Land Procurement for Public Interest Development). Ulayat land of Hiripau Adat Law Community was used to develop public interest by Regent of Mimika Regency. In 2012, Regent of Mimika Regency files appeal to Jayapura High Court against Andreas Kaokapaitiparo because according to Jayapura District Court Decision Number 12/Pdt/2013/PT. Jpr, dated 12 September 2012, Regent of Mimika does not pay the compensation based on Sales Value of Taxable Object; therefore he is obliged to pay the rest of the compensation. According to Sales Value of Taxable Object, compensation which shall be paid is 7.2 billion, but the regent only pays 2.5 billion; therefore the regent shall pay another 4.7 billion. High Court of Jayapura nullifies Jayapura District Court Decision Number 12/Pdt/2013/PT. Jpr, dated 12 September 2012. High Court Jayapura argues that 2,5 billions is the compensation which has been agreed during deliberation as proven in minutes of the meeting. Since the compensation has been agreed and documented in minutes of meeting, compensation shall not be determined based on Sales Value of Taxable Object. Unfortunately, High Court does not consider whether the deliberation has been conducted based on free, prior, and informed consent from Adat Law Community. High Court only relies on written evident brought by the Regent of Mimika Regency.

Compensation is constructed as fair replacement value given to rightful party in the process of land procurement. Fair replacement value of land used for public interest according to Presidential Regulation Number 36 of 2005 regarding Land Procurement for Public Interest Development is calculated based on land title, building, plant, and objects related to land. This presidential regulation has not calculated non-physical loss suffered by the rightful party. Special for land of Adat Law Community, compensation of ulayat land of Adat Law Community shall be given in the form of public facility development or other form beneficial for the community. Rightful parties are reluctant to release their land title because given compensation is only calculated based on physical aspect which focus on economic value and neglect non-physical aspect, such as sociological and philosophical loss (Maleh 2015: 9-14). In 2012, Presidential Regulation Number 36 of 2005 is revoked by the issuance of Law Number 2 of 2012 regarding Land Procurement for Development of Public Interest as explained above. In this law, compensation has not only been evaluated based on physical loss, but also non-physical loss of rightful parties. Valuation according to this law has left valuation based on Sales Value of Taxable Object and used market value and calculates physical and non-physical loss suffered by rightful parties. Physical loss is valued calculated based on market value of property and nonphysical loss is calculated based on subjective valuation of the rightful owner (Effendi 2015).

Yustisia Jurnal Hukum Volume 9 Number 3 (September-December 2020) The Existence of Adat Law ... 316 
According to 306 Indonesia Valuation Standard, non-physical loss which can be compensated are loss of profession and emotional loss (solatium); rest of the land which is not used by development project; transaction cost, such as moving cost or notary cost; other physical loss; and opportunity loss. Compensation given towards non-physical loss as gradual bonus of compensation in the form of solatium after compensation according to market value is given (Effendi 2015: 108). Solatium is compensation given to owner of the house to compensate non-financial loss suffered by necessity to transfer and/or to move as impact of land procurement (Komite Penyusun Standar Penilaian Indonesia and Masyarakat Profesi Indonesia 2014: 14). For example non-physical loss compensated during land procurement in Toll Road in Depok is calculated based on potential loss of income since the land is used for business activity and emotional loss calculated based on type of house and duration of living according to percentage table within the 306 Indonesia Valuation Standard (Effendi 2015: 108).

\section{Critics towards Compensation as Fair Replacement Value in Adat Law Community's Land Used for Infrastructure Development}

By considering this, valuation of non-physical loss has not valued sociological loss which elaborated as historical land authorization which hereditary enjoyed and created memories for the rightful parties about the land (Maleh 2015: 43). In case of ulayat land, this compensation has not valued identity loss suffered by Adat Law Community by releasing their land right. Government only focus of compensation in the form of money or physical loss suffered by the community (Maleh 2015: 146).

In Papua, though Adat Law Community has been recognized by Papua Special Autonomy Law and Distinct Regional Regulation, Kholongkhe ulayat land of Ondikeleuw Tribe which legally owned by Amos Ondikeleuw as Head of Ondikeleuw Tribe through Sentani Adat Court Decision Number 394/PRASS/X/2010, dated 8 September 1999, and strengthen by Letter of Recognition towards ownership of Kholongkhe ulayat land, dated 22 December 2008. This land is claimed by Government as state land according to Letter issued by Minister of Home Affair Number 13SD.21/7/1, dated 9 March 1973 regarding inventory of movable and immovable goods in Irian Jaya Province (today it is Papua) and Governor Letter Number 95/61.j/1976 regarding to Papua Police regarding transfer of registered movable and immovable goods used of government institution in provincial level.

Amos Ondikeleuw as Head of Ondikeleuw Tribe sells his land to Sri Hartati and Khairuddin Thalib, then Police of Jayapura accuses Sri Hartati and Khairuddin Thalib conducting unlawful possession towards state land. Amos Ondikeleuw as Head of Ondikeleuw Tribe bring this case to Jayapura District Court. Jayapura District Court Decision Number 07/Pdt.G/2014/PN JPR, dated 21 May 2014 is in favour of claimant. The Court decides that Amos Ondikeleuw is lawful owner of Kholongkhe ulayat land; land transfer to Sri Hartati and Khairuddin Thalib is lawful; Police of Jayapura authorization towards Kholongkhe ulayat land is unlawful; therefore Police of Jayapura shall return back the land to claimant. Jayapura District Court considers that during inclusion of Irian Jaya within the territory of Indonesia in 1969, Adat law institution has not been established; 
therefore it shall be believed that institution which administer Adat Law of communities living in Irian Jaya is the government, Governor of Irian Jaya Province. Governor shall acknowledge land title at that time either under ulayat land of Adat Law Community, individual land of Adat Law Community's member, or state land.

At that time, land title settlement is conducted deliberately by the communities and formal land transfer by written document is not common. According to Minister of Home Affair Regulation Number 15 of 1975 regarding Land Procurement Procedure which applicable at that time, land of Adat Law Community can be released for public or private interest by receiving compensation. Once the Adat Law Community has received compensation, the community shall release their right over land. During the Court session, it not proven that Ondikeleuw Tribe has released their ulayat land; therefore District Court argues that Sentani Adat Court Decision shall be applied retroactively. Disputed object is decided by Jayapura District Court Decision Number 07/Pdt.G/2014/PN JPR as land owned by the Adat Law Community.

Unsatisfied with District Court Decision, Police of Jayapura submits appeal to High Court. High Court nullifies District Court Decision by considering that state land authorized by Police of Jayapura through Letters issued by Minister of Home Affair and by Governor are legal, while Sentani Adat Court Decision regarding land title is illegal since it shall not be applied retroactively. Sentani Adat Court Decision is decision issued to protect right of Adat Law Community which regulated in Papua Special Autonomy Law. Unfortunately, High Court neglects the basic idea of the issuance of Papua Special Autonomy Law is to protect the rights of Papuan indigenous peoples based on respect of custom and culture (Sumule 2002: 14; Sumule 2003: 366). Jayapura High Court is more focus on legal certainty according to document issued by Minister of Home Affair and Irian Jaya Governor without further examine background behind the issuance of the letters.

Not only in this case, land procurement of ulayat land for Local Government housing in Jayapura also creates tension with Afaar Tribe. Demianus M. Afaar, heir of Afaar Tribe, files lawsuit against Papua Governor for unlawful development project above ulayat land of Nonomiweci which hereditary owned by Afaar Tribe. The claimant has neither released nor received compensation from this development; therefore claimant sues Governor of Papua to to return back the land or to pay compensation. Jayapura District Court Decision Number 85/Pdt.G/2013/PN Jpr, dated 7 April 2014, is in favor of the claimant and order defendant to return back the disputed object to claimant or to pay compensation. Defendant submits appeal to Jayapura High Court. Jayapura High Court Decision Number 53/PDT/2014/PT JAP, dated 29 October 2014, revokes decision of Jayapura District Court because is not proven that Afaar tribe is the legal owner of the disputed land since the land is registered under Right to Use Certificate issued by Land Registrar Office and held by Papua Local Government. Defendant argues that this certificate is lawfully obtained based on Letter of Land Title Release from, dated 5th July 1973. Jayapura High Court neglects the fact that Jayapura District Court has proven that Petrus Hamadi, head of Afaar Tribe, does not sign or handle over Letter of Land Title Release to Papua Local Government and the community has not received 
compensation; therefore issuance of Right to Use Certificate as legal basic to build Local Government of Cigombong Kotaraja housing has no legitimate foundation. Later on, claimant's second appeal is rejected by Supreme Court Decision Number 864 K/Pdt/2015, dated 27 July 2015. These two cases show that District Court decision strengthens right of Adat Law Community as subjects which has right towards compensation, while High Court judges more focus on availability of land certificate without considering the legality of the issuance of the certificate itself.

From these cases, once land is under title of state land, it is hard to claim back as ulayat land, even though the Adat Law Community has been legally recognized and they can prove that they have neither release their land right nor receive compensation. Conceptually speaking, when ulayat land has been compensated either received directly by Adat Law Community or deposited in District Court, Adat Law Community has no longer legal relation with their land. Meanwhile, as guaranteed in the Constitution, Adat Law Community has traditional right (ulayat right) which has distinct character. According to Constitutional Court Decision Number 3/PUU-VIII/2010, dated 9 June 2011, distinct character of Adat Law Community's right is that the right can not be abolished when the community still exists. Concept of compensation which restrict or release hereditary right of Adat Law Community is in contrary with concept of ulayat right and traditional right which can not be limited since it shall be enjoyed hereditary because compensation is only enjoyed at the time it is given (Constitutional Court Decision Number 3/PUU-VIII/2010: 163). This is in contrary with Republic of Indonesia Constitution where right of Adat Law Community shall be recognized and protected. Since right of Adat Law Community is legally protected, government can not unilaterally compensate land of Adat Law Community (Kusumadara 2013: 6).

Moreover, Adat Law Community perceives land not only as source of economic income, but also as sacred place and identity (Mebri 2017: 69; Cahyono, et.al 2016: 928; Ginting and Espinosa 2016: 3; Sumardjono 2018: 58). As explained above, compensation is valued only based on physical loss and non-physical loss and has not valued sociological loss of the community; therefore compensation will not 'fairly' replace their loss of identity and religious bonding of Adat Law Community with their sacred land. By considering this situation, instead of compensating ulayat land of Adat Law Community for infrastructure development in Public-Private Partnership, Adat Law Community shall be within collaboration action between Private and Public Authorities as elaborated below.

\section{Adat Law Community as a Public Entity in PPP: a Proposal}

The conventional approach of government to monopoly its roles for infrastructure development has shifted to a more fluid constellation using state-relational approach (Bell and Hindmoor, 2009: 1). This new constellation has shifted the state-centric approach and has brought other actors, including non government organizations (NGOs), private corporations, and communities to have roles in delivering public service. State-relational approach opens the opportunity for the government to establish a partnership with other actors to cope the limitation of resources and capacity, money and technology. In this new 
approach, the government has formed partnership with other actors to achieve government's goals. However, the government still be placed as the pivotal player, who decides the rule of the game of the partnership (Bell and Hindmoor, 2009: 4).

The strategy of state-relational approach is the New Public Management concept under public administration study. The NPM has introduced the concept of inviting other actors to help the government in providing services for society, through the scheme of Public-Private Partnership (PPP). This scheme is aiming to govern better rather than to govern less (Bell and Hindmoor, 2009: 2). This is because in this new constellation, it broadens and expands the scope and the scale of governance. The government are trying to expand their governing capacities not only by strengthening their central role but by strengthening new governance partnerships with a range of private actors (Hood, 1991: $3)$.

In NPM, the private sector is considered to be a better provider of public services than government (Hood, 1991: 3). The private sector characteristics, such as professional management, explicit standards and measures of performance; managing by results; and value for money; are some of the underlying reasons for this assumption (Rhodes, 1997: 655). The broad evidence of the inefficient and ineffective capacity of the government in providing public service (Pessoa, 2010: 529; Keating ,2004: 3; Nsasira et.al., 2013:48) and the state limited financial resources have forced the state to collaborate with private sector (Keating, 2004: 5).

The complexity between the lack of resources and inefficiency in public service sector has commenced calls for a new relationship between governments and other sectors through NPM (Nsasira et.al. 2013:48). The NPM has highlighted the importance to 'modify' the public management to achieve better quality service, especially for long-term projects, such as infrastructure establishment (Nsasira et.al. 2013: 48; Hood 1991: 3). One of the strategies is increasing private sector involvement in public service through establishment of Public-Private Partnerships (PPP) (Nsasira et.al. 2013: 48; Hood 1991: 3).

This new constellation makes the actors have convergence goal, while retain specific values for each actors. For the government, public interest is the ultimate goal which needs to be achieved; and it may differ with the main orientation from the private corporations, which is profit. Hence, distinguished value between corporations and communities as other actors, beside the government, need to be acknowledged, respected and if applicable, compromised. The public and private sectors have, at least in theory, distinct goals, structures and management styles (Farnham and Horton, 1993: 36). Whereas government is considered to pursue the public good, private sector organizations are considered to pursue financial gains/profits (Farnham and Horton, 1993: 36).

The main criticisms of PPP is the long-term cost of 'paying' the private sector to run the infrastructure, which may be more than it would cost the public sector to build it themselves (Wettenhall, 2007: 396). Some scholars believe that there is an opportunity to utilize PPP as 'covert privatization' especially in developing countries (Wettenhall, 2007: 396) which may bring more imbalance effect between stakeholders, government, companies, and communities. Nevertheless, as long as the PPP approach have been based 
on some 'genuine' partnership characteristics, such as: 'a collaborative, interactive form of mixing; horizontal, non-hierarchical relationships between the parties; consensual decision-making; an ability to achieve synergies between involved people and organizations; and use of respect and trust as major forms of social capital' (Wettenhall, 2007: 395), the approach can be beneficial to both the government and the non-state actor. The government can get instant required fund and a long-period of paying instalments, the residents can get a better quality services from the 'improvement' approach of management and the private sectors can get profits from their initial investment capital.

Conceptually, there is no universal definition about PPP, and many scholars have their own definitions of PPP. In the UN General Assembly 2005, PPP was defined as 'voluntary and collaborative relationship between various parties, both state and non-state, in which all participants agree to work together to achieve a common purpose or undertake a specific task and to share risks and responsibilities, resources and benefits' (Bull, 2010: 480). Koppenjan, as cited in Nsasira et.al (2013: 52) defines PPP as a long-term institution of cooperation between public and private actors in developing products and services with risks, costs, and resources sharing. Another definition comes from Regan, who defines PPP as the 'procurement contract of goods and services utilizing, franchising and similar arrangements by the private sector on behalf of the government' (Nsasira et.al. 2013: 52). In line with those definitions, Brinkerhoff and Brinkerhoff (2011: 3) defined PPP as 'working arrangements based on a mutual commitment (over and above that implied in any contract) between a public sector organizations with any other organization outside the public sector.' From those definitions, there are some common ideas regarding the characteristics of PPP, such as the parties involved (which are public and private actors), the requirement to work together to achieve certain goals and risk sharing. However, from Regan's and Brinkerhoff's, there is also significant different upon whether the PPP are merely 'contracts' or mutual commitment above contractual deals. Based on those definitions, PPP may have one essential characteristic: a contractual basis. Based on the contract, the ownership status and the outputs of a PPP approach can be distinct from general firm alliances, which are always public, or at least quasi-public, in goods or services (Nsasira et.al. 2013: 51). Moreover, beyond the definitions and financial engineering, the debate on PPP has also articulated regarding the conceptual framework of PPP as the new strategy (Hodge et.al 2010: 3). The claim as the 'language game' and 'rhetorical framing device' from government to cover privatization on public service is a challenge that needs to be answered in PPP implementation (Hodge et.al 2010: 4). The implementation of PPP became more popular after multilateral financial institutions, such as World Bank, have reduced the percentage loan for financing infrastructure (Noumba-Um, 2010: 457) and the financial crisis in 1997 (Meidute and Pailulis, 2011: 259). The PPP approach represents a 'procurement tool' that can be used when the government is facing financial constraint or significant deficiencies in the development of infrastructure projects (Noumba-Um 2010: 457). The capital-intensive requirement in initial stage of the projects has made PPP approach as an 'instant' solution to solve the problems in infrastructure projects (Noumba-Um, 2010: 471; Meidute and Paliulis, 2011: 258). In PPP, the government gets involved into the later stage process, and the initial period, as the most capital-intensive stage, is handed over to the private business sector (Meidute and Paliulis, 2011: 259). 
Moreover, PPP has provided an opportunity to share managerial experience from the private sector to the government officers, which may increase the human resources quality in public service (Meidute and Paliulis, 2011: 259).

Ironically, the increasing human resource quality in public service as the main goal of infrastructure development may not be achieved, if the sustainability of the PPP project is unclear. Based on research conducted by Setiawan and Sukma, in Indonesian infrastructure development, the social/community legitimacy is one of the keys of development success (Setiawan and Sukma, 2012: 2). Therefore, a more participative PPP is inevitable in infrastructure development, especially in a project with wide stakeholders such as land procurement for infrastructure (Yuli Ernis, 2013: 1). However, most PPP literatures explain more about the distribution of role between public and private entity without elaborating who can be those entities and the role of community in those dichotomy. As an affected stakeholder from the project, the community is often left behind and disregarded from the discussion regarding PPP (Sapto Hermawan, 2019: 11). For example, in Indonesian Presidential Regulation No. 67 Year 2005, which revised by Presidential Regulation No. 38 Year 2015 concerning State and Business Entity Partnership in Infrastructure Procurement, the parties which may referred to the community are not found. This regulation is the Indonesian government's guideline for investors who want to join any project under the PPP scheme.

In this guideline, the government mentioned numerous parties which can be involved in this scheme (see the graph below) (Kementerian Koordinator Bidang Perekonomian 2010: 4).

\begin{tabular}{|l|c|c|}
\hline \multicolumn{3}{|c|}{ Fund and Investors } \\
\hline Project Insurer & Project Sponsors (Equity) & Banks (Loan) \\
\hline
\end{tabular}

\begin{tabular}{|c|c|c|c|}
\hline \multicolumn{4}{|c|}{ Government Bodies } \\
\hline Ministry of Finance & Licensing Body & $\begin{array}{c}\text { State Contracting } \\
\text { Agency }\end{array}$ & Advisory Body \\
\hline \multicolumn{3}{|c|}{ Third Parties (Sub-Contactor) } \\
\hline EPC Contractor & O\&M Operator & Off-Taker Service Provider \\
\hline
\end{tabular}

Diagram 2. Parties Involved in PPP Scheme

In (normal) partnership, parties are able to determine with whom they want to make contract. In PPP, the party who can decide this matter is the government. The government has an authority to decide the rule of the game in partnership. The authority as public entity makes the government capable to determine who will be granted public entity status (also) in PPP (because there is no exact classification for public entity in PPP). 
There is an urgency to determine the status of the actors in PPP because there is a possibility that the government is not the only controller towards the resources, for example: land.

In Indonesia, land title can be held/owned by individuals, state and Adat Law Community. Adat Law Community is recognized as controller of the land in Basic Agrarian Law. Adat Law Community controls their land through ulayat right (Article 3 Basic Agrarian Law). Ulayat right is defined as right to control and right to own over land and its natural resources which collectively authorized by Adat Law Community (West Sumatera Regional Regulation Number 6 of 2008 regarding Ulayat Land and Its Utilization). Ulayat Right is similar to beschikkingrecht in Adat Law literature. Beschikkingrecht is term introduced by Van Vollenhoven which explained by Ter Haar as the right of a group of people to internally regulate how the members collect resource from their land and to externally restrict outsider take unlawful benefit from their land (Ter Haar 2013: 49-50). Ter Haar says that right to bechikken is absolute, including right to transfer land title, but according to Van Vollenhoven one of beschikkingrecht distinct character is prohibition to transfer the land (Ter Haar, 2013: 50; Constitutional Court Decision Number 3/PUU-VIII/2010).

Since Adat Law Community also has right to control over its land, Adat Law Community can also be considered as public entity in the scheme of PPP. They have the right to determine, how they are going to manage their land for their interest. The issue is raising up, when the interest of Adat Law Community is 'different' from the 'public' interest on behalf of infrastructure development through the scheme of PPP. The role of Adat Law Community as controller over their land should be accommodated along with the development strategy under the government planning. The Basic Agrarian Law, especially Article 2 (4) should be respected to synchronize this gap. Based on this Article, State Right to control can be authorized to Adat law Community, therefore the Adat Law Community can 'replace' the government to represent the controller toward the land.

Beside as controller over their land, Adat Law Community is also the owner of their land based on Minister Agrarian and Spatial Planning Regulation No. 10 Year 2016 concerning Procedure to Stipulate Communal Land Right of Adat Law Community and Community in Particular Area, especially in Article 20. Thus, Adat Law Community can be 'classified' as public in PPP. In the recent Indonesian Law, Adat Law Community's communal ownership towards land is acknowledged as Communal Right under Minister Agrarian and Spatial Planning Regulation No. 10 Year 2016. Despite the debate between ulayat right and Communal Right, based on this regulation, the Communal Right of Adat Law Community can be cooperated with third party based on consensus and law. As the owner of the land, in the PPP scheme Adat Law Community shall be treated as party, which participate in the whole process of PPP, including procurement, construction, commissioning, and operational phase.

Adat Law Community can be classified as public entity, which 'replace' position of the government (especially in PPP) in dealing with third party toward their land. There is an approach namely "attributing public status toward interest groups" respected in political sociology which argues that the government is able to determine any group to 
be public entity, even the groups are not match with the criteria of public entity (Offe 1991: 15). Based on Offe's explanation, any corporate which can do specific purpose helps the government functions, can be attributed as public entity from the government (Offe 1991: 15). From the explanation of this possibility to attribute public status to any entity, this can be a basis to strengthen why the government is possible to attribute it to Adat Law Community. The existence of Adat Law Community, which can act more likely like a state (in a limited region) can justifies why the government can start to consider this step as further consistence regarding the recognition of Adat Law Community. The first step of recognition through promulgating regional regulations is already applied. Therefore, more political will from the government is needed. This argument is align with Soekowati's argument which stated that any entity in certain law nature can have public authority as long as the government declare that they are public entity (Ali, 1999: 49). Explanation regarding the character of Adat Law Community has given significant clues that Adat Law Community can be the public entity in PPP.

The terminology of Adat Law Community is specifically used in Indonesia context. In other countries, some complicated issues regarding the position of indigenous people's right and its implementation has brought several examples, in how the state dealing with the right of indigenous people. In New Zealand, Maori tribe as its indigenous people need to prove their correlation with land, to be able to do legal relation with another party (Simarmata and Steny, 2016: 30). In India, the condition is slightly different because the status as public entity is already held by indigenous people community (Adivasi Village) and it makes them capable to deal with third party, including corporations which want to invest in their region (Simarmata and Steny, 2016 : 39). Align with New Zealand and India, in the Philippines, indigenous people community has established a foundation to ease agreement dealing process. This breakthrough has succeed to parse law dilemma and to maximize economic benefit compared to traditional ownership (Simarmata and Steny, 2016: 54-57)

Adat Law Community's right is having significant difference with right based on liberalism-individualism politics philosophy which more usual acknowledged by state, especially state which did not have experience being colonized. The communal right, which commonly raised from social pluralism in ex-colonized countries still difficult to be understood by the colonizer countries (Simarmata and Steny, 2016: 62). Therefore, the more contextual and specific regulations are needed to bridge the gap between the right recognition of 'common' right and Adat Law Community's right. The recognition of the subject should be consistent to deliver the benefit to the community, by respecting rights, territories, resources and cultures of Adat Law Community. Giving the community a selfesteem to take active participation and recognizing them into a more strategic position, as key decision makers and as an expert in matters that affect them, is align with the minimum standard of good practice in practicing indigenous people right (Secretariat of the United Nations Permanent Forum on Indigenous Issues: 2). The community should not being placed under guardianship of a state and the state should give the community a right to determine their livelihood. Hence, considering there is possibility that the peoples inside the community feel that they are not capable enough to decide strategic action toward their land, the participation of the state is still needed through facultative 
regulation, for example: a safeguard. The non-repressive regulation can be through a forum of consultation between the community and the state before the 'public entity' decides the 'next plan' for Adat Law Community's land. This safeguard has been adopted by the government of Philippines (De Vera 2017; Simarmata and Steny, 2016: 65), thus this kind of breakthrough hopefully can parse the 'unfair' compensation for Adat Law Community since term compensation would be changed into participation.

\section{Conclusion}

Land determines the identity and existence of Adat Law Community. Releasing the land used for infrastructure development procurement will abolish the identity of the community. It have shown that failure in recognizing Adat Law Community as rightful party over their land neglects their right to entitle compensation. Moreover, compensation paid to them is often unfairly replacing the loss they suffer. By considering above explanations, instead of economically compensating ulayat land of Adat Law Community used for infrastructure development, Adat Law Community's participation shall be involved in infrastructure development on their land. The active participation of Adat Law Community can be exercised through placing the community as public entity in PPP. This argument based on the similar characteristics between ulayat right of Adat Law Community and right to control held by the state.

State has power to possibly attribute public status to any entity. The categorisation of public entity in PPP is over reliant to government's preference; therefore public entity should not only be 'monopolized' by the government (. Recently, international, national, and local legal framework have recognized the existence and the rights of Adat Law Community to manage and regulate their own territory. This proposal is relying upon another step which government can take to give a chance to Adat Law Community to exercise their self-determination principle. It might not be able to answer, whether involving Adat Law Community in PPP is going to make infrastructure development more successful. Yet, a more participating PPP with Adat Law Community's involvement as part of this scheme is promising to embrace their existence, as learnt from some cases from other countries in dealing with their indigenous people. For example is in China, land which is collectively owned in rural areas which will be converted into state-owned land through land acquisition, the State does not pay according to market prices to farmers. However, it provides a compensation package that includes employment opportunities for farmers, housing compensation, compensation for crop loss, and / or granting a residence permit in urban areas. This can at least make them eligible for their social welfare such as health insurance, pensions and / or retirement plans, access to highquality schools and subsidized agricultural goods that were not previously available to farmers (Ding 2003:3). This breakthrough is going to reduce future latent conflict with the community in maintaining the sustainability of the PPP project. On the other side, safeguarding this mechanism is still needed to bring possibility to the community to get assistance from the government. This is because participatory does not mean appointing another 'government' to deliver public service, but to collaborate with 'check and balancer' to govern better. 


\section{Notes:}

1. The Merauke Integrated Food and Energy Estate (MIFEE) project as one of Masterplan for Acceleration and Expansion of Indonesia's Economic Development (MP3EI's) components is under the narrative of green energy and food security. This project facilitates domestic and foreign investments targeting 1.2 million hectares of Marind Adat Law Community's customary forest. This forest is perceived as unproductive land that shall be turned into productive land. Meanwhile $75 \%$ of the land allocated to this project consist of natural forest with 350.000 hectares of peat land. Moreover, impact of investments towards indigenous people in the project area are human rights violations, marginalization, poverty and environmental degradation. (Ito, Rahma \& Savitri, 2014; Awas Mifee, 2012; Global Witness, 2005; DTE, 2011; Telapak \& EIA, 2005 and 2009; Franciscans International, 2011; Obidzinki, et. al., 2013; FPP \& Sawit Watch, 2006; Friends of the Earth, LifeMosaic and Sawit Watch, 2008 as cited by Ginting and Epinosa, 2016).

2. Governor of Central Java argues that potentially affected community of PT Semen Gresik (Persero) Tbk factory establishment has participated in the preparation of Environmental Impact Document and socialization of the factory establishment. The participation is proven by written document. Meanwhile, there is declaration signed by 2.501 members of potentially affected community which reject the establishment of the factory in their surrounding area. Supreme Court says that the essence of socialization is not only limited to formality procedure, but also obligation to consider the effectiveness or success of delivering information directly or indirectly to all communities member and in accordance to their language and social structure. Government as administrator of welfare state shall protect citizen, respect rights of community, and accommodate each of objection and explain resolution. By considering this, Supreme Court argues that potentially affected community of PT Semen Gresik (Persero) Tbk factory establishment has not participated in the socialization of the project because the message delivered from the government has not been well received by the community. As proven by the declaration, the community is resistant towards the project introduced by the Governor of Central Java. See, Supreme Court Number 99PK/TUN/2016, pg. 111-112.

3. Mining Permit consists of Exploration Permit and Production Operation Permit. By Law, there is no obligation for the government to invite people's participation in granting mining permit. Applicants shall only submit planning of community development and empowerment surrounding mining area; therefore there is no any room where community can speak up their interest towards the mining activity in their livelihood. There is no chance for potentially affected community's objection towards mining activity in their area, unless there is force majeure. See Law Number 4 of 2009 regarding Mineral and Coal.

4. According to Minister of Home Affair Regulation Number 52 of 2014 regarding Guideline to Recognize and Respect Adat Law Community, recognition and protection towards Adat Law Community shall be started from identification of Adat Law Community. Identification shall pay attention to the history; territory; law; 
wealth and/or properties; and structure/system of governance of the community. Territory of Adat Law Community are Adat land (ulayat land), including land, water, and natural resources with particular boundaries. This land is hereditary and sustainability owned, utilized and preserved to fulfill the need of the community. This land is transferred through inheritance from ancestor or ownership claim over Adat forest or ulayat land. Therefore for Adat Law Community, losing land means losing identity as Adat Law Community.

5. See land procurement of Sentani Airport in Jayapura Regency; land procurement of Cigombong Kotaraja Government housing.

6. See procurement of ulayat land of Hiripau Adat Law Community by Regent of Mimika Regency in Jayapura District Court Decision Number 12/Pdt/2013/PT. Jpr.

7. In the discussion of 1945 Constitution of the Republic of Indonesia, Sandra Moniaga says right of Adat Law Community which often disrespected is their right to selfdetermination. Right to self-determination is not right to be independent. It is an autonomous right to regulate and manage their own territory according to their law and governance system. The state shall recognize, respect, and protect this right. (Constitutional Court, 1141).

8. See Article 5, 18 and 27 UNDRIP.

9. See Article 18B (2) of the 1945 Constitution Republic of Indonesia.

10. Epistema notes that there are 538 Adat Law Communities have been stipulated through regional law product after Constitutional Court Decision Number 35/PUUX/2012 issued on 16 May 2013 (Epistema, 2017). For example, Regional Regulation of Lebak Regency, Banten Province Number 8 of 2015 regarding Recognition, Protection, and Empowerment of Kasepuhan Adat Law Community recognizes, respects and protects 522 Adat Law Communities in Lebak Regency which consist of pupuhu kasepuhan, sesepuh kampung, and sesepuh rendangan/gumulan.

11. Recognition towards Adat Law Community is regulated in Minister of Home Affair Regulation Number 52 of 2014 regarding Guideline to Recognize and Respect Adat Law Community. Steps to recognize and protect Adat Law Community are identification; verification and validation; and stipulation through regional regulation.

\section{BIBLIOGRAPHY:}

\section{Books:}

Bell, S and Hindmoor, A. (2009). Rethinking Governance: The Centrality of the State in Modern Society. Cambridge University Press: Cambridge.

Brinkerhoff, D.W. and Brinkerhoff J.M. (2011). 'Public-Private Partnership: Perspectives on Purposes', Publicness and Good Governance.' Public Administration and Development Vol. 31(1): 2-14.siep?

Bull, B. (2010). 'Public-Private Partnership: The United Nations Experience', in Hodge, G.A., Greve. C., and Boardman, A.E. (Eds). (2010). International Handbook on PublicPrivate Partnerships. Edward Elgar: Cheltenham. 
Cahyono, Eko, et.al. (2016). Konflik Agraria Masyarakat Hukum Adat atas Wilayahnya di Kawasan Hutan. Komisi Nasional Hak Asasi Manusia Republik Indonesia. Jakarta.

Constitutional Court Republic of Indonesia. (2010). Naskah Komprehensif Perubahan Undang-Undang Dasar Negara Republik Indonesia Tahun 1945 Latar Belakang, Proses, dan Hasil Pembahasan 1999-2002 Buku IV Kekuasaan Pemerintahan Negara Jilid 2 Edisi Revisi. Sekretariat Jenderal dan Kepaniteraan Mahkamah Konstitusi. Jakarta.

Davidson, Jamie and David Henley. (2007). The Development of Tradition in Indonesia Politics: The Deployment of Adat from Colonialism to Indigenism. Routledge. London

Ding, Chengri. (2003). Land Policy Reform in China: Assessment and Prospects. Land Use Policy. Volume 20/2.

Effendi, Arief Erman. (2015), Analisis Nilai Ganti Kerugian Berbasis Standar Penilaian Indonesia 306 Dalam Rangka Pengadaan Tanah Untuk Kepentingan Umum (Studi Kasus Jalan Tol Ruas Depok-Antasari Di Wilayah Krukut Depok). Tesis. Universitas Gadjah Mada. Yogyakarta.

Erni, Christian (Ed.), (2008), the Concept of Indigenous Peoples in Asia A Resource Book, International Work Group for Indigenous Affairs (IWGIA) and Asia Indigenous Peoples Pact Foundation, Copenhagen and Chiang Mai.

Ernis, Yuli. (2013). Pelaksanaan Pengadaan Tanah Bagi Pembangunan Untuk Kepentingan Umum. Research Report. Badan Pembinaan Hukum Nasional. Jakarta.

Farnham, D. and Horton, S. (1993). Managing Private and Public Organisation, Basingstoke: Macmillan.s.

Feiring, Birgitte. (2013). Indigenous Peoples' Rights to Lands, Territories, and Resources. International Land Coalition. Rome.

Hodge, G. A., Greve, C. and Boardman, A.E. (2010). 'Introduction: The PPP Phenomenon and Its Evaluation' in International Handbook on Public Private Partnerships. (eds) Hodge, G.A., Greve. C. and Boardman, A.E. Edward Elgar: Cheltenham.sep?

Keating, M. 2004. 'Introduction: Are markets on tap or on top?' In Who Rules? How Government Retains Control of a Privatised Economy. Sydney: Federation Press: 1-15. is

Kementerian Koordinator Bidang Perekonomian, (2010), Panduan Bagi Investor dalam Investasi Bidang Infrastruktur, Jakarta.

Kementerian Lingkungan Hidup dan Kehutanan. (2017). Laporan Kinerja 2017. Biro Perencanaan Kementerian Lingkungan Hidup dan Kehutanan. Jakarta.

Komite Penyusun Standar Penilaian Indonesia and Masyarakat Profesi Indonesia. 2014. Petunjuk Teknis Penilaian Terhadap PEngadaan Tanah Bagi Pembangunan untuk Kepentingan Umum (SPI 306).

Maleh, Taheta Jaya. (2015). Urgensi Kepentingan Umum, Model Kompensasi Dan Strategi Penyelesaian Konflik Dalam Pengadaan Tanah Bagi Pembangunan Untuk Kepentingan Umum Di Indonesia (Analisis Isi Terhadap UU No 2 Tahun 2012 Tentang Pengadaan Tanah Bagi Pembangunan Untuk Kepentingan Umum). Tesis. Universitas Gadjah Mada. Yogyakarta.

McNichols, Dan. (2012). The United States: The World's Largest Emerging P3 Market (Rebuilding America's Infrastructure). Star America Infrastructure Fund 
Noumba-Um, P. (2010). 'Empirical Evidence of Infrastructure Public-Private Partnerships: Lesson from the World Bank Experience' in Hodge, G.A., Greve. C., and Boardman, A.E. (eds). 2010. International Handbook on Public-Private Partnerships. Edward Elgar: Cheltenham.

Nugroho, Bambang Daru. (2008). Pengelolaan Hak Ulayat Kehutanan yang Berkeadilan dalam Kaitannya Pemberian Izin HPH Dihubungkan dengan Hak Mengusai Negara atas Sumber Daya Alam. Dissertation. Universitas Padjajaran. Bandung.

Nurjaya, I Nyoman. Adat Community Lands Right as Defined Within the State Agrarian Law of Indonesia: Is It a Genuine or Pseudo-Legal Recognition? paper. Presented at the 16 ' $\mathrm{h}$ International Congress of the Commission on Legal Pluralism jointly organized by The Commission on Legal Pluralism and Department of Social and Cultural Anthropology University of Zurich on August 31 to September 3, 2009 at University of Zurich, Switzerland.

Pessoa, A. (2010). 'Reviewing Public- Private Partnership Performance in Developing Economics' in Hodge, G.A., Greve. C., and Boardman, A.E. (eds). 2010. International Handbook on Public-Private Partnerships. Edward Elgar: Cheltenham.

Pujosewojo, Kusumadi. (1971). Pedoman Pelajaran Tata Hukum Indonesia. Aksara. Jakarta.

Sudiyat, Iman, et. al. (1978). Masalah Hak Ulayat di Wilayah Bekas Karesidenan Madura.

Research Report. Faculty of Law Universitas Gadjah Mada. Yogyakarta.

Sumardjono, Maria S.W. (2018). Regulasi Pertanahan dan Semangat Keadilan Agraria. STPN Press. Yogyakarta.

Sumule, Agus. (2002). Protection and Empowerment of the Rights of Indigenous People of Papua (Irian Jaya) Over Natural Resources under Special Autonomy: from Legal Opportunities to Challenge of Implementation. The Australian National University. Canberra.

United Nations Economic and Social Council. (2012). Analysis of the Duty of the State to Protect Indigenous Peoples affected by Transnational Corporations and Other Business Enterprises. Eleventh Session Permanent Forum on Indigenous Issues. New York.

\section{Journals:}

Burger, Phillipe and Hawkesworth, Ian. (2011). How To Attain Value for Money: Comparing PPP and Traditional Infrastructure Public Procurement. OECD Journal on Budgeting. Volume 2011/1.

De Royer, S., et. al. Self-identification of Indigenous People in Post-Independence Indonesia: A Historical Analysis $\mathrm{n}$ the Context of REDD+. International Forestry Review Vol 17(3), 2015.

Ginting, Wiranta Yudha. (2016). Indigenous Resistance to Land Grabbing in Merauke, Indonesia: The Importance and Limits of Identity Politics and The Global-Local Coalitions. International Journal of Social Science and Business Vol. 1 Bo. 3 November.

Hermawan, S. (2019). Pembabakan Kebijakan Lingkungan Hidup Nasional Berbasis Kearifan Lokal sebagai Strategi Adaptasi Menghadapi Perubahan Iklim. Majalah Ilmiah Cakrawala Hukum, 21(1), 1-11. 
Hermawan, S. (2019, October). Law and Economic Approach to Reduce Marine Plastic Litter in Indonesia. In 3rd International Conference on Globalization of Law and Local Wisdom (ICGLOW 2019). Atlantis Press.

Hood, C. (1991). 'A Public Management for All Season?.' Public Administration Vol. 69 (1): 3-19.

Ismail, Nurhasan. Arah Politik Hukum Pertanahan dan Perlindungan Kepemilikan Tanah Masyarakat, Jurnal Recht Vinding Media Pembinaan Hukum Nasional Volume 1 Nomor 1 Januari-April 2012.

Koeswahyono, I. (2008). Melacak Dasar Konstitusional Pengadaan Tanah Untuk Kepentingan Pembangunan Bagi Umum. dimuat dalam Artikel Jurnal Konstitusi, 1.

Kusumadara, Afifah. (2013). Perkembangan Hak Negara atas Tanah: Hak Menguasai atau Hak Memiliki?. Jurnal Media Hukum Vol. 20 No. 2.

Mebri, Jhon A. (2017). Kedudukan Hak atas Tanah Masyarakat Hukum Adat untuk Kepentingan Umum. Jurnal Ilmu Hukum.

Meidute, I., and Paliulis, N.K. (2011). 'Feasibility Study of Public Private Partnership'. International Journal of Strategic Property Management Vol. 15(3): 257-274.

Nsasira, R., Basheka, B.C., and Oluka, P.N. (2013). 'Public Private Partnerships (PPP) and Enhanced Service Delivery in Uganda: Implications from the Energy Sector.' International Journal of Business Administration Vol.4 (3): 48-60.

Rahmi, Elita. Eksistensi Hak Pengelolaan atas Tanah (HPL) dan Realitas Pembangunan Indonesia. Jurnal Dinamika Hukum Vol. 10 No. 3 September 2010.

Reynaers, A. (2013). 'Public Values in Public Private Partnerships.' Public Administration Review Vol. 74(1): 44-50.

Rhodes, R. (1997). 'The new governance: governing without government.' Political Studies Vol 4(4): 652-667

Setiawan, Tomi dan Sukma Egnas. (2012). Public Private Partnership as a Public Service Dilemma, dalam BISNIS \& BIROKRASI: Jurnal Ilmu Administrasi dan Organisasi, Vol 19, No 3 Tahun 2012. http://journal.ui.ac.id/index.php/jbb/article/view/ 1855.

Sumule. Agus. (2003). Swimming against the Current: the Drafting of the Special Autonomy Bill for the Province of Papua and Its Passage through the National Parliament of Indonesia. The Journal of Pacific History, Vol. 38, No. 3.

Sunderlin, Willian D., et.al. (2000). The Effect of Indonesia's Economic Crisis on Small Farmers and Natural Forest Cover in the Outer Islands. Occasional Paper No (28)E, Center for International Forestry Research. Jakarta.

Weihe, Guorio. (2008). Public-Private Partnership and Public Public-Private Value TradeOffs. Journal of Public Money \& Management, 01 June 2008, Vol. 28(3), p. 153-158.

Wettenhall, R. (2007). 'ActewAGL: a genuine public-private partnership?' International Journal of Public Sector Management Vol. 20(5): 392-414

\section{Internet:}


Anugrah, Iqra. (2019). The Conversation. http://theconversation.com/cek-faktaapakah-peningkatan-biaya-pembebasan-lahan-akan-menghilangkan-konflikkonflik-agraria-112426. (accessed 12 February 2020).

De Vera, David E. (2017). Indigenous Peoples in the Philippines: A Country Case Study. Can be accesed through $h t t p: / / w w w . i a p a d . o r g / w p$-content/uploads/2015/07/devera_ip_phl.pdf

Epistema. (2017). 538 Komunitas Masyarakat Hukum Adat Ditetapkan Pasca Putusan MK 35. Epistema. http://epistema.or.id/kabar/siaran-pers/komunitas-masyarakathukum-adat/ (accessed 18 August 2018). 